\title{
Upaya Meningkatkan Hasil Belajar Statistika Melalui Media Video Pembelajaran Pada Siswa Kelas IV SD Negeri 02 Trengguli
}

\author{
Kurnia Febry Tri Hastuti \\ Universitas Sebelas Maret \\ kurniafebry28@gmail.com
}

\section{Article History}

received 30/4/2021

revised 30/5/2021

accepted 30/6/2021

\begin{abstract}
The purpose of this study is to improve statistical learning outcomes for fourth grade students of SD Negeri 02 Trengguli, Jenawi District, Karanganyar Regency for the 2020/2021 Academic Year by using learning video media. This research is classroom action research, which consists of two cycles and each cycle has several stages, namely planning, implementation, observation and reflection. The results of this study indicate that through the media video learning can improve the statistical learning outcomes of fourth grade students of SD Negeri 02 Trengguli, this can be seen from the initial conditions (Pre-Cycle) showing the average student learning outcomes are 66 with a 50\% completeness percentage. In Cycle I, the average student learning outcomes were 72 with a completeness percentage of $71 \%$. And in Cycle II the average student learning outcomes were 81 with a percentage of completeness $86 \%$. This shows that the learning video media can improve the statistical learning outcomes of fourth grade students of SD Negeri 02 Trengguli.
\end{abstract}

Keywords: Learning Outcomes, Statistics, Learning Video Media

\begin{abstract}
Abstrak
Tujuan penelitian ini yaitu untuk meningkatkan hasil belajar statistika pada siswa kelas IV SD Negeri 02 Trengguli Kecamatan Jenawi Kabupaten Karanganyar Tahun Pelajaran 2020/2021 dengan menggunakan media video pembelajaran. Penelitian ini adalah penelitian tindakan kelas, yang terdiri dari dua siklus dan setiap siklusnya memiliki beberapa tahapan yaitu perencanaan, pelaksanaan, pengamatan dan refleksi. Hasil dari penelitian ini menunjukkan bahwa melalui media video pembelajaran dapat meningkatkan hasil belajar statistika siswa kelas IV SD Negeri 02 Trengguli, hal ini terlihat dari kondisi awal (Pra Siklus) menunjukkan ratarata hasil belajar siswa adalah 66 dengan persentase ketuntasan $50 \%$. Pada Siklus I rata-rata hasil belajar siswa adalah 72 dengan persentase ketuntasan $71 \%$. Dan pada Siklus II rata-rata hasil belajar siswa adalah 81 dengan persentase ketuntasan $86 \%$. Hal ini menunjukkan bahwa media video pembelajaran dapat meningkatkan hasil belajar statistika siswa kelas IV SD Negeri 02 Trengguli.
\end{abstract}

Kata kunci: Hasil Belajar, Statistika, Media Video Pembelajaran 


\section{PENDAHULUAN}

Menurut Undang-Undang Republik Indonesia Nomor 20 Tahun 2003 Pasal 1 Ayat 1 menyebutkan bahwa pendidikan adalah usaha sadar dan terencana untuk mewujudkan suasana belajar dan proses pembelajaran agar peserta didik secara aktif mengembangkan potensi dirinya untuk memiliki kekuatan spiritual keagamaan, pengendalian diri, kepribadian, kecerdasan, akhlak mulia, serta ketrampilan yang diperlukan dirinya, masyarakat, bangsa dan negara. Untuk mewujudkan Undangundang tersebut guru diharapkan mampu menciptakan pembelajaran yang sesuai dengan karakteristik peserta didik sehingga pembelajaran dapat berjalan dengan baik, lancar dan menyenangkan sehingga peserta didik menjadi aktif dan mampu mengembangkan potensinya dengan maksimal.

Karena pada umumnya setiap siswa memiliki kecerdasan yang berbeda-beda. Menurut Howard Gardner (2013: 42-43), seorang ilmuwan yang menemukan teori Multiple Intelligence menyatakan bahwa kecerdasan berkaitan dengan kemampuan untuk memecahkan masalah dan menciptakan produk serta karya dalam sebuah konteks yang kaya dan keadaan naturalistik. Dalam teorinya, Gardner mengelompokkan kemampuan-kemampuan manusia menjadi 8 bagian, yaitu kecerdasan lingustik, logis-matematis, spasial, kinestik-tubuh, musikal, interpersonal, dan naturalis. Adanya pengelompokkan kecerdasan tersebut, Robert E. Slavin (2011 :165) menyatakan bahwa jika manusia memiliki kepribadian dan kecerdasan yang berbeda, manusia pun memiliki cara belajar yang berbeda-beda. Ada beberapa siswa memiliki gaya belajar visual, artinya lebih mudah dalam menangkap dan memahami materi apabila melihat gambar. Dan ada beberapa siswa memiliki gaya belajar auditif, artinya lebih mudah dalam menangkap dan memahami materi apabila dengan mendengarkan suara.

Dengan adanya pengelompokkan kecerdasan itu, ketidakberhasilan siswa bukan sepenuhnya kesalahan siswa itu sendiri, guru diharapkan mampu mengintrospeksi diri dalam kegiatan belajar mengajar yang ia lakukan. Kemungkinan, ketidakberhasilan siswa dapat disebabkan oleh siswa kurang bersemangat dalam pembelajaran, metode pembelajaran guru yang membosankan ataupun tanpa menggunakan media pembelajaran yang menarik bagi siswa. Sehingga siswa menjadi tidak memperhatikan guru dalam kegiatan proses mengajar.

Seperti halnya kegiatan pembelajaran di kelas IV SDN 02 Trengguli. Berdasarkan hasil pengamatan yang telah peneliti lakukan, guru kelas IV SDN 02 Trengguli dalam melaksanakan pembelajaran menggunakan metode ceramah dan belum menggunakan media pembelajaran, dimana siswa bertindak sebagai pelaku pasif dalam kegiatan belajar mengajar. Dan siswa cenderung kurang fokus dan kurang memperhatikan guru ketika pembelajaran berlangsung, sehingga siswa tidak dapat menerima pembelajaran dengan baik.

Matematika adalah salah satu mata pelajaran yang penting dalam dunia pendidikan. Didalam mata pelajaran matematika, peserta didik didorong untuk berfikir matematis, berlogika, berfikir kritis, berkomunikasi dengan baik dan mampu memprediksi serta mengambil keputusan dengan baik. Tentunya hal-hal tersebut sangat bermanfaat dalam kehidupan sehari-hari. Tetapi, tidak sedikit siswa yang menganggap matematika adalah mata pelajaran yang menakutkan. Dan pembelajarannyapun terasa monoton dan membosankan, sehingga banyak peserta didik yang merasa tidak terlalu tertarik dengan pembelajaran matematika. Maka dari itu, guru diharapkan mampu menciptakan suasana pembelajaran yang inspiratif dan menyenangkan. Sehingga siswa akan menjadi lebih interaktif, termotivasi untuk berpartisipasi aktif dalam proses pembelajaran.

Tujuan pembelajaran akan tercapai apabila hasil belajar statistika siswa mencapai KKM yang telah ditetapkan sekolah yaitu sebesar 65. Namun pada ulangan harian dengan materi statistika, dari 14 siswa kelas IV SDN 02 Trengguli 50\% siswa 
hasil belajarnya berada dibawah KKM. Rendahnya hasil belajar tersebut tidak terlepas dari kurangnya variasi media pembelajaran yang digunakan oleh guru. Melihat banyaknya siswa yang hasil belajarnya masih dibawah $\mathrm{KKM}$, hendaknya guru menggunakan media pembelajaran yang menarik perhatian siswa. Sehingga siswa menjadi tertarik dan senang dalam kegiatan pembelajaran.

Kata media berasal dari Bahasa latin dan adalah bentuk jamak dari kata medium yang secara harfiah artinya adalah "perantara" atau "pengantar". Kata kunci media adalah "perantara". Pratiwi (2018: 36) menyatakan bahwa media pembelajaran adalah salah satu faktor yang dapat memotivasi siswa dalam melaksanakan pembelajaran dan mampu mendorong siswa untuk mencapai hasil belajar yang maksimal.

Gagne dan Briggs dalam Arsyad (2017: 4) menyatakan bahwa secara implisit media pembelajaran meliputi alat yang secara fisik digunakan untuk menyampaikan isi materi pembelajaran, yang terdiri dari antara lain adalah buku, tape recorder, kaset, video camera, video recorder, film, slide (gambar bingkai), foto, gambar, grafik, televisi dan computer. Sedangkan Adam (2015) menyatakan dalam jurnalnya bahwa media pembelajaran adalah segala sesuatu baik berupa fisik maupun teknis dalam proses pembelajaran yang dapat membantu guru untuk memudahkan dalam menyampaikan materi pembelajaran kepada siswa sehingga memudahkan tercapainya tujuan pembelajaran. Salah satu media pembelajaran yang dapat memudahkan guru dalam pembelajaran dan dapat menarik perhatian siswa adalah media video pembelajaran.

Media video pembelajaran adalah media pembelajaran yang sangat disukai oleh siswa sekolah dasar, karena didalamnya terdapat serangkaian gambar gerak yang disertai suara dan membentuk suatu kesatuan yang dirangkai menjadi alur serta menampilkan pesan guna tercapainya tujuan pembelajaran. Sehingga dalam pembelajaran matematika dengan menggunakan media video pembelajaran dapat menarik perhatian dan memotivasi siswa sehingga mereka bisa mencermati materi pembelajaran dengan baik dan mudah. Pembelajaran dengan menggunakan video pembelajaran dapat memberikan kesempatan pada siswa untuk bereksplorasi, aktif dan pembelajaran menjadi lebih menyenangkan.

Video pembelajaran dapat digunakan sebagai media pembelajaran yang efektif, karena sifat media yang sederhana tetapi mengasyikan dapat membuat siswa semangat dan antusias dalam pembelajaran. Dengan media video pembelajaran ini diharapkan mampu meningkatkan hasil belajar siswa. Juga sebagai bentuk kegiatan siswa untuk mengalami, bukan transfer pengetahuan dari guru ke siswa. Siswa mengerti apa makna belajar, apa manfaatnya, mereka dalam status apa dan bagaimana mencapainya sehingga mereka menyadari bahwa yang mereka pelajari berguna bagi hidupnya, untuk itu mereka akan berupaya untuk mencapainya. Dengan beberapa hal tersebut, maka peneliti melaksanakan penelitian tindakan kelas dengan judul "Upaya Meningkatkan Hasil Belajar Statistika Melalui Media Video Pembelajaran Pada Siswa Kelas IV SD Negeri 02 Trengguli Kecamatan Jenawi Kabupaten Karanganyar Tahun Pelajaran 2020/2021".

\section{METODE}

Penelitian ini adalah penelitian tindakan kelas, yang terdiri dari dua siklus dan setiap siklusnya memiliki beberapa tahapan yaitu perencanaan, pelaksanaan, pengamatan dan refleksi (Kurt Lewin). Siklus I dilaksanakan pada hari Rabu, 3 Maret 2021 dan siklus II dilaksanakan pada hari Selasa, 16 Maret 2021. Subjek penelitian ini adalah siswa kelas IV Sekolah Dasar Negeri 02 Trengguli yang berjumlah 14 siswa, terdiri dari 6 laki-laki dan 8 perempuan. Teknik pengumpulan data dalam penelitian ini menggunakan teknik observasi, teknik wawancara, teknik tes, dan dokumentasi. Dan uji validitas data pada penelitian ini menggunakan triangulasi sumber dan triangulasi teknik. 


\section{HASIL DAN PEMBAHASAN}

Siklus I ini dilaksanakan pada hari Rabu, 3 Maret 2021. Pelaksanaan siklus I ini secara luring di dalam kelas, didukung dengan kondisi wilayah Kecamatan Jenawi yang tergolong zona aman dan hijau serta sesuai kebijakan dari sekolah terkait pelaksanaan pembelajaran luring dengan tetap menerapkan protokol kesehatan dan pembatasan jam pembelajaran. Peneliti menyiapkan kegiatan pembelajaran yang akan dilaksanakan, yaitu dengan menyusun silabus, rencana pelaksanaan pembelajaran (RPP) terlebih dahulu, dan menyiapkan media video pembelajaran, lembar kerja peserta didik (LKPD), dan soal evaluasi beserta instrument penilaiannya.

Berdasarkan hasil dari soal evaluasi yang telah diberikan pada siklus I, dapat diketahui sebagai berikut:

Tabel 1. Hasil Belajar Siswa Siklus I

\begin{tabular}{ccccc}
\hline No & Interval & KKM & $\begin{array}{c}\text { Jumlah } \\
\text { Siswa }\end{array}$ & $\begin{array}{c}\text { Persentase } \\
\text { Siswa }\end{array}$ \\
\hline 1 & $81-85$ & 66 & 1 & $7,1 \%$ \\
2 & $76-80$ & 66 & 5 & $35,8 \%$ \\
3 & $71-75$ & 66 & 3 & $21,4 \%$ \\
4 & $66-70$ & 66 & 1 & $7,1 \%$ \\
5 & $61-65$ & 66 & 4 & $28,6 \%$ \\
Jumlah & & 14 & $100 \%$ \\
Jumlah Nilai & \multicolumn{3}{c}{1007} \\
Rata-rata Nilai & \multicolumn{3}{c}{72} \\
Jumlah Siswa Tuntas & \multicolumn{3}{c}{40} \\
Jumlah Siswa Belum Tuntas & \multicolumn{3}{c}{$71 \%$} \\
Persentase Ketuntasan & & \multicolumn{3}{c}{} \\
\hline
\end{tabular}

Adapun hasil observasi dari peneliti terkait pelaksanaan kegiatan pembelajaran pada siklus I ini yang perlu mendapat perbaikan adalah:

1. Guru perlu menyiapkan rancangan pembelajaran cadangan, sehingga apabila rancangan yang pertama mengalami kendala bisa menggunakan rancangan pembelajaran yang lain. Karena, pada pelaksanaan siklus I ini terjadi pemadaman listrik di wilayah sekolah. Sehingga, guru tidak bisa menampilkan video pembalajaran melalui LCD Proyektor.

2. Hasil belajar siswa pada siklus I ini belum mencapai indikator keberhasilan, maka dari itu peneliti memutuskan untuk melanjutkan ke siklus selanjutnya guna tercapainya indikator keberhasilan yang sudah ditetapkan.

Dikarenakan persentase ketuntasan masih $71 \%$ dengan nilai rata-rata 72 , maka penelitian ini dilanjutkan ke siklus selanjutnya yaitu Siklus II.

Seperti halnya pada siklus I, pada siklus II ini peneliti juga merencanakan kegitan pembelajaran yang akan dilaksanakan, yaitu dengan menyusun silabus, rencana pelaksanaan pembelajaran (RPP) terlebih dahulu, dan menyiapkan media video pembelajaran yang menarik, link zoom meeting, lembar kerja peserta didik (LKPD), soal evaluasi beserta instrumen penilaiannya. Siklus II ini dilaksanakan pada hari Selasa, 16 Maret 2021. Pelaksanaan siklus II ini secara daring (dalam jaringan) melalui aplikasi Zoom meeting. Yaitu sesuai peraturan sekolah yang terbaru bahwasanya semua pembelajaran dilaksanakan secara daring, karena situasi dan kondisi wilayah Kecamatan Jenawi yang angka covidnya meningkat. Dalam pelaksanaan pembelajaran secara daring ini, pada malam hari sebelum hari pembelajaran dimulai, peneliti mengingatkan dan mengirimkan jadwal zoom meeting yang akan dilaksanakan kepada siswa melalui whatsapp group. Pada saat pelaksanaan pembelajaran, peneliti melaksanakan sesuai dengan rancangan 
pembelajaran yang sudah dirumuskan, dan tidak lupa memberikan stimulus-stimulus kepada siswa sehingga pembelajaran dapat berjalan dengan baik dan lancar. Dan penggunaan media video pembelajaran dapat membuat siswa menjadi lebih tertarik dan lebih antusias, sehingga pembelajaran matematika dapat berjalan dengan baik dan menyenangkan.

Berdasarkan hasil dari soal evaluasi yang telah diberikan pada siklus II, dapat diketahui sebagai berikut:

Tabel 2. Hasil Belajar Matematika Siklus II

\begin{tabular}{ccccc}
\hline No & Interval & KKM & $\begin{array}{c}\text { Jumlah } \\
\text { Siswa }\end{array}$ & $\begin{array}{c}\text { Persentase } \\
\text { Siswa }\end{array}$ \\
\hline 1 & $96-100$ & 66 & 1 & $7,1 \%$ \\
2 & $91-95$ & 66 & 1 & $7,1 \%$ \\
3 & $86-90$ & 66 & 3 & $21,5 \%$ \\
4 & $81-85$ & 66 & 1 & $7,1 \%$ \\
5 & $76-80$ & 66 & 4 & $28,6 \%$ \\
6 & $71-75$ & 66 & 1 & $7,1 \%$ \\
7 & $66-70$ & 66 & 1 & $7,1 \%$ \\
8 & $61-65$ & 66 & 2 & $14,4 \%$ \\
Jumlah & & 14 & $100 \%$ \\
Jumlah Nilai & & \multicolumn{3}{c}{1130} \\
Rata-rata Nilai & \multicolumn{3}{c}{12} \\
Jumlah Siswa Tuntas \\
Jumlah Siswa Belum Tuntas \\
Persentase Ketuntasan
\end{tabular}

Refleksi yang dilakukan peneliti setelah melaksanakan kegiatan pembelajaran pada siklus II adalah sebagai berikut:

1. Penggunaan media video pembelajaran terbukti dapat meningkatkan hasil belajar statistika pada siswa Kelas IV SDN 02 Trengguli.

2. Persentase ketuntasan adalah $86 \%$ dengan rata-rata nilai 81 .

3. Penggunaan media video pembelajaran dapat membuat siswa menjadi lebih bersemangat, lebih aktif dan lebih berantusias sehingga pembelajaran menjadi lebih hidup dan menyenangkan.

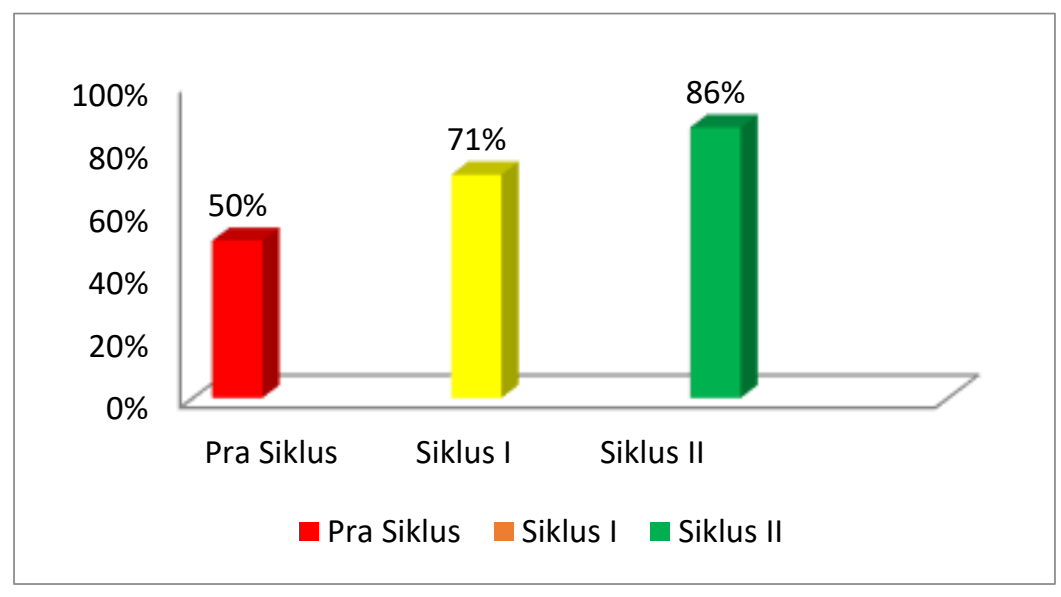

Gambar 1. Grafik Persentase Perbandingan Ketuntasan Hasil Belajar Matematika Pra Siklus, Siklus I dengan Siklus II 
Dari grafik diatas menunjukkan, bahwa di setiap siklus pelaksanaan pembelajaran statistika terdapat peningkatan hasil belajar. Yang artinya dengan penggunaan media video pembelajaran ini dapat menarik dan memotivasi siswa dalam pembelajaran statistika sehingga persentase ketuntasan belajar siswa mencapai indikator keberhasilan yang diharapkan.

Hasil penelitian dari dua siklus tersebut, dapat dijelaskan bahwa:

a. Nilai terendah yang diperoleh siswa pada Pra Siklus yaitu 51, pada Siklus I yaitu 60 dan pada siklus II yaitu 65 .

b. Nilai tertinggi yang diperoleh siswa pada Pra Siklus yaitu 78, pada Siklus I yaitu 81 dan pada siklus II yaitu 98 .

c. Nilai rata-rata kelas mengalami peningkatan yaitu pada Pra Siklus nilai rata-rata yaitu 66 , pada Siklus I nilai rata-rata yaitu 72 dan pada Siklus II nilai rata-rata yaitu 81.

d. Persentase ketuntasan belajar siswa pada Pra Siklus yaitu 50\%, pada Siklus I yaitu $71 \%$ dan pada Siklus II yaitu $86 \%$.

Hal tersebut membuktikan bahwa penggunaan media video pembelajaran dapat meningkatkan hasil belajar statistika pada siswa Kelas IV SDN 02 Trengguli Kecamatan Jenawi Kabupaten Karanganyar Tahun Pelajaran 2020/2021.

\section{SIMPULAN}

Berdasarkan hasil penelitian dan pembahasan, maka dapat disimpulkan bahwa penggunaan media video pembelajaran dapat meningkatkan hasil belajar statistika pada siswa kelas IV SD Negeri 02 Trengguli. Video yang digunakan dalam pembelajaran matematika ini berbeda dengan video pada umumnya, yaitu adanya pemberian gambar dan musik yang menarik sehingga disukai oleh siswa. Hal ini sesuai dengan pendapat Pratiwi (2018: 36) bahwa dengan penggunaan media pembelajaran dapat membuat siswa menjadi lebih tertarik, aktif dan bersemangat dalam pembelajaran dan tidak lagi merasa bosan dalam memahami dan menyelesaikan pengoalahan data dengan benar. Sehingga terjadi peningkatan hasil belajar statistika pada siswa kelas IV Sekolah Dasar Negeri 02 Trengguli Kecamatan Jenawi Kabupaten Karanganyar Tahun Pelajaran 2020/2021 melalui penggunanan media video pembelajaran. Peningkatan tersebut dapat dilihat dari persentase ketuntasan siswa pada Pra Siklus yaitu 50\% dari jumlah siswa, kemudian pada Siklus I mengalami peningkatan menjadi $71 \%$ dan pada siklus II juga mengalami peningkatan menjadi $86 \%$.

\section{DAFTAR PUSTAKA}

Adam, S. \& Syastra, M.T. (2015). Pemanfaatan Media Pembelajaran Berbasis Teknologi Informasi Bagi Siswa Kelas X SMA Ananda Batam. Jurnal: CBIS Journal, 3 (2), hlm. 78-90.

Arsyad, A. (2017). Media Pembelajaran. Jakarta: PT Rajagrafindo Persada.

E. Slavin, Robert. (2011). Psikologi Pendidikan, Teori dan Praktik. Jakarta: Indeks.

Gardner, Howard. (2013). Multiple Intelligences, Kecerdasan Majemuk Teori dalam Praktik. Tangerang Selatan: Interaksara.

Nurlevia, D. (2016). Pengaruh Penggunaan Media Pembelajaran Audio Visual dalam Hasil Belajar IPA Kelas $V$ di Sekolah Dasar Negeri 35 Pontianak. Jurnal: Pendidikan dan Pembelajaran Khatulistiwa, 5 (3), hlm. 1-11.

Pardjono. (2007). Model dan Desain Penelitian Tindakan Kelas. Makalah disampaikan dalam Pelatihan PTK bagi CPNS Dosen UNY.

Pratiwi. (2018). Media Pembelajaran. Yogyakarta: Gava Media.

Sugiyono. (2013). Metode Penelitian Pendidikan Pendekatan Kuantitatif dan Kualitatif. Bandung: Alfabeta.

Undang-Undang Republik Indonesia Nomor 20 Tahun 2003 tentang Sistem Pendidikan Nasional. Jakarta: Penulis. 